\title{
PERAN PEREMPUAN DALAM PENGENTASAN KEMISKINAN DI DESA WISATA GABUGAN,SLEMAN, DAERAH ISTIMEWA YOGYAKARTA
}

\author{
HASTUTI \\ Fakultas Ilmu Sosial, UNY \\ hj.hastuti@yahoo.com
}

\begin{abstract}
Abstrak
Penelitian ini bertujuan mengetahui karakteristik perempuan rumah tangga miskin, dan upaya yang dilakukan untuk pengentasan kemiskinandi Desa Wisata Gabugan, Sleman. Metode yang digunakan adalah deskriptifkuantitatif. Hasil penelitian menunjukkan bahwa sebagai petani, rendahnya tingkat pendidikan, dan sempitnya penguasaan lahan. Upaya yang dilakukan perempuan untuk pengentasan kemiskinan dengan melakukan diversifikasi usaha, mensiasati pengeluaran terkait pemenuhan kebutuhan pangan, sandang, dan kepentingan sosial. Pengentasan kemiskinan juga dilakukan dengan mengerahkan seluruh anggota rumah tangga ikut bekerja agar memperoleh pendapatan, berhutang untuk memenuhi kebutuhan rumah tangga miskin, melakukan migrasi untuk mencari sumber pendapatan di wilayah lain, dan memanfaatkan famili untuk pengentasan kemiskinan. Kendala pengentasan kemiskinan adalah keterbatasan dalam akses terhadap kesehatan, pendidikan yang memadai, kesempatan berusaha dan memperoleh sumber pendapatan, sanitasi kurang memadai dan ketidaksetaraan gender juga menjadi kendala di wilayah penelitian.
\end{abstract}

Kata Kunci: perempuan, pengentasan kemiskinan

\begin{abstract}
This study aims to investigate the characteristics of women of poor households, and the efforts made to alleviate poverty at Gabugan Tourism Village, Sleman. The method used is quantitative deskriptive. The results showed that poor households women of childbearing age dominated by the principal livelihood as farmers, low levels of education, and the limited tenure. Efforts by women to poverty alleviation by diversifying the business, anticipate expenses related food needs, clothing, and social interests. Poverty alleviation is also done by deploying all household members go to work in order to earn income, debt to meet the needs of poor households migrate to seek other sources of income in the region, and utilizing the family to poverty alleviation. Poverty alleviation constraints are limitations in access to health, adequate education, employment and sources of income, inadequate sanitation and gender inequality is also an obstacle in the research area.
\end{abstract}

Keywords: women, poverty eradication 


\section{PENDAHULUAN}

Laki-laki dan perempuan memiliki pengalaman kemiskinan yang berbeda dengan dampak yang diakibatkan oleh kemiskinan juga berbeda antara laki-laki dan perempuan.Permasalahan kemiskinan yang banyak dialami perempuan berasal dari akar budaya patriarki, budaya tersebut bekerja melalui pendekatan, metodologi, dan paradigma pembangunan. Praktek pembangunan yang bersifat hegemoni dan patriarki, serta pengambilan keputusan yang hirarkis telah meminggirkan perempuan secara sistematis dalam beberapa kebijakan, program, dan lembaga yang tidak responsif gender. Pengambilan keputusan, penyusunan program dan pembuatan kebijakan, tidak mampu mengungkap dinamika kehidupan perempuan dan laki-laki secara berkeadilan. Ketimpangan gender sering menjadi akar penyebab ketidakberdayaan perempuan untuk akses terhadap sumber daya yang tersedia sehingga kelompok perempuan menjadi terpuruk dalam kemiskinan.

Kemiskinan menyebabkan masyarakat desa rela mengorbankan apa saja demi keselamatan hidup (safety life), mempertaruhkan tenaga secara fisik untuk memproduksi keuntungan bagi tengkulak lokal dan menerima upah yang tidak sepadan dengan tenaga yang dikeluarkan(Scott dalam David A Cotter, 2002).Keterbatasan pengetahuan, pendidikan, keterampilan, modal, dan sistem nilai di perdesaan menjadi kendala utama masyarakat miskin dalam memperoleh akses dan kontrol terhadap sumber daya yang ada termasuk sumberdaya untuk kegiatan ekonomi di perdesaan. Keinginan perempuan untuk mampu melepaskan dari belenggu kemiskinan, kegigihan, kesungguhan, dan keuletan rumah tangga miskin menjadi salah satu modal dasar untuk pengentasan kemiskinan sehingga akan selalu perempuan berusaha dapat memiliki sumber pendapatan sendiri.

MDG's 2015 memperhatikan perempuan mengingat sepertiga penduduk dunia yang hidup di bawah garis kemiskinan, sekitar 70 persennya perempuan. Di Indonesia, dari jumlah penduduk miskin yang mencapai 31,02 juta jiwa, sebesar 70 persen dari mereka adalah perempuan(BPS, 2011). Perempuan sebagai sumberdaya manusia, seha- rusnya tidak ada perbedaankualitas dengan lawan jenisnya, namun konstruksi sosial sering membuat perempuan tertinggal. Di masyarakat perbedaan peran perempuan dengan laki-laki memiliki implikasi pada terjadinya ketimpangan dalam pembagian kerja dan penguasaan sumberdaya sehingga pendapatan yang diperoleh antara laki-laki dan perempuan berbeda meski dengan jenis pekerjaan yang hampir sama. Ketimpangan telah memarjinalkan perempuan sehingga mengalami subordinasi. Tugas utama laki-laki adalah mencari nafkah untuk pemenuhan kebutuhan rumah tangga, perempuan yang ikut mencari nafkah tak serta merta mampu melepaskan tugas utama menyelesaikan pekerjaan rumah tangga. Tuntutan pemenuhan kebutuhan dan perkembangan saat ini menempatkan perempuan tidak hanya mengelola rumah tangga, karena berbagai alasan perempuan terpaksa ikut mencari nafkah meskipun tugas rumah tangga tetap harus menjadi tanggung jawab perempuan. Keterlibatan perempuan bekerja guna memperoleh pendapatan tidak serta merta mampu meningkatkan posisi tawar perempuan. Fenomena tersebut mengundang para ahli untuk melakukan kajian lebih mendalam melalui penelitian, diskusi ilmiah, bahkan internalisasi melalui institusi pemerintah. Ketika rumah tangga mengalami kemiskinan, perempuan akan berupaya dengan berbagai cara agar seluruh anggota rumah tangga tidak mengalami penderitaan akibat kemiskinan.

Sumber daya alam, sosial, dan berbagai kegiatan sosial dan budaya yang dilakukan kelompok remaja, karang taruna, ibu-ibu dan kelompok bapak-bapak dapat dimanfaatkan untuk pengembangan pariwisata yang dikemas sebagai kegiatan yang memberikan sumbangan pendapatan rumah tangga. Yogyakarta dengan pengembangan wisata alam banyak diminati wisatawan baik domestik maupun manca negara. Kombinasi usaha inovatif sumberdaya fisik dapat dikombinasikan 
dengan usahatani dengan pengembangan agrowisata salak, agrowisata tanaman hias, perkemahan, panjat tebing, wisata alam lain, dan kegiatan penelitian menjadi sumber pendapatan bagi masyarakat dan memiliki peran penting sebagai sumber pendapatan daerah (lihat Baiquni, 2006). Geliat wisata dengan mengembangkan desa wisata pada beberapa wilayah pedesaan diharapkan sebagai pencerahan bagi perempuan di perdesaan untuk terlibat dalam kegiatan tersebut. Pengembangan ekonomi di perdesaan berbasis pada berbagai kegiatan yang berkembang diharapkan menjadi sumber pendapatan di perdesaan sehingga membebaskan masyarakat di perdesaan dari belenggu kemiskinan. Kegiatan perdesaan dengan pengembangan desa sebagai tujuan wisata dimanfaatkan perempuan untuk melakukan kegiatan yang memberikan ssumber pendapatan tanpa harus meninggalkan tugas utamanya sebagai ibu rumah tangga.

Mendasarkan latar belakang yang telah disampaikan maka dikemukakan masalah penelitian terkait rumah tangga miskin, upaya perempuan untuk pengentasan kemiskinan dan kendala yang dihadapi perempuan dalam pengentasan kemiskinan

Studi di perdesaan Jawa Barat menye butkan tekanan ekonomi memaksa perempuan harus bekerja demi kelangsungan hidup (Sajogyo, 1986). Pada kondisi terhimpit kemiskinan meskipun tugas utama perempuan bukan sebagai pencari nafkah, memaksa perempuan mencari kesempatan memperoleh pendapatan guna pemenuhan kebutuhan rumah tangga. Sumbangan pendapatan perempuan sangat membantu bagi rumah tangga miskin dalam meringankan beban rumah tangga.

Kemiskinan sangat erat dengan perdesaan, bahwa 69 persen lebih penduduk perdesaan tergolong miskin dan bekerja di sektor pertanian (BPS, 2011). Upaya pengentasan kemiskinan sesuai dengan program dari Bank Dunia dilakukan melalui tiga strategi pengentasan kemiskinan (UNDP, 2006). Tiga strategi pengentasan kemiskinan: 1 . Memperluas kesempatan (promoting opportunity) kegiatan ekonomi masyarakat miskin. 2.
Memperlancar proses pemberdayaan (facilitating empowerment) dengan pengembangan kelembagaan untuk masyarakat miskin dengan penghapusan hambatan sosial bagi pengentasan kemiskinan. 3. Memperluas dan memperdalam jaring pengaman (enhancing security) agar masyarakat miskin memiliki kemampuan dalam pengelolaan resiko efek negatif dari penguatan kebijakan stabilitasi makroekonomi. Chambers (1983) menyampaikan konsep perangkap deprivasi (concept of devrivation trap) yang menganalisa penyebab kemiskinan sebagai hubungan sebab akibat yang saling kait mengkait bak lingkaran setan (vicious circle) antara ketidakberdayaan (powerless), kemiskinan (poverty), kerapuhan (vulnerability), kelemahan fisik (physical weakness), dan keterasingan (isolution). Memisahkan mata rantai kemiskinan merupakan upaya yang dianggap dapat membebaskan masyarakat miskin dari ketidakberdayaan sehingga menumbuhkan kekuatan dan memiliki kemandirian secara ekonomi.

Menurut Bappenas bahwa masyarakat desa dapat dikatakan miskin jika salah satu indikator berikut ini terpenuhi seperti; (1) kurangnya kesempatan memperoleh pendidikan; (2) memiliki lahan dan modal pertanian yang terbatas; (3) tidak adanya kesempatan menikmati investasi di sektor pertanian; (4) kurangnya kesempatan memperoleh kredit usaha; (4) tidak terpenuhinya salah satu kebutuhan dasar (pangan, papan, perumahan); (5) berurbanisasi ke kota; (6) menggunakan cara-cara pertanian tradisional; (7) kurangnya produktivitas usaha; (8) tidak adanya tabungan; (9) kesehatan yang kurang terjamin; (10) tidak memiliki asuransi dan jaminan sosial; (11) terjadinya korupsi, kolusi dan nepotisme dalam pemerintahan desa; (12) tidak memiliki akses untuk memperoleh air bersih; (13) tidak adanya partisipasi dalam pengambilan keputusan publik. Keterbatasan aksesibilitas dan infrastruktur di perdesaan serta belum adanya pengelolaan perdesaan secara optimal karena kualitas sumber daya manusia yang belum memadai menjadikan wilayah perdesaan masih harus berkutat dalam kemiskinan. 


\section{METODE}

Pemilihan lokasi dilakukan sesuai topik penelitian terkait perempuan dan pengentasan kemiskinan, maka dipilih sebagai lokasi penelitian di Desa Wisata Gabugan, Sleman. Pemilihan sampel tidak dilakukan karena seluruh populasi perempuan yang telah berumah tangga di wilayah penelitian dan termasuk dalam rumah tangga miskin dijadikan responden penelitian.Pengumpulan data untuk memperoleh data primer dan data sekunder meliputi, studi pustaka, observasi dan penjajaga, dan wawancara.Variabel penelitian adalah profil rumah tangga perempuan, kegiatan rumah tangga, ekonomi, dan sosial kemasyarakatan, pendapatan rumah tangga, dan pengentasan kemiskinan. Analisis data digunakan tabel frekuensi untuk menjelaskan mengenai pola dan distribusi karakteristik variabel-variabel tersebut. Nilai frekuensi relatif diperoleh dari frekuensi tiap kelas dibagi jumlah keseluruhan observasi kali 100. Analisis deskriptif kuantitatif dilakukan mendasarkan pada asosiasi untuk mengetahui pola dan distribusi fenomena, yang diperkuat dari hasil observasi di lapangan.

\section{HASIL DAN PEMBAHASAN}

Wilayah penelitian termasuk dalam wilayah administratif Kabupaten Sleman, penggunaan lahan didominasi lahan pertanian berupa lahan tegal, pekarangan, dan sawah dengan tanaman pangan guna konsumsi sendiri dan sebagian dijual untuk memenuhi berbagai kebutuhan sehari- hari. Tanaman salak menjadi tanaman yang mendominasi pada lahan tegal dan pekarangan, bahkan saat ini tanaman salak juga telah banyak ditanam di lahan sawah. Kegiatan pertanian masih menjadi sumber pendapatan utama di wilayah penelitian yakni dari usahatani bercocok tanam dan peternakan.

Umur ikut menentukan kemampuan dalam menyelesaikan pekerjaanpada kegiatan pertanian yang mengandalkan tenaga kerja manusia. Umur yang relatif muda memiliki kemampuan fisik lebih baik,maka lebih berpotensi dapat menyelesaikan pekerjaan pertanian dan peternakan dengan lebih baik dibanding kelompok umur yang lebih tua dengan kondisi fisik yang kurang optimal.

Distribusi umur responden dapat dilihat pada tabel 1 berikut:

Tabel 1. Perempuan Menurut Umur

\begin{tabular}{rrrr}
\hline No & Umur (tahun) & f & $\%$ \\
\hline 1 & $<30$ & 3 & 7,5 \\
2 & $30-39$ & 6 & 15 \\
3 & $40-49$ & 18 & 45 \\
4 & $50-59$ & 8 & 20 \\
5 & $>60$ & 5 & 12,5 \\
& Jumlah & 40 & $100 \%$ \\
\hline
\end{tabular}

(Sumber: Data primer tahun 2014)

Pemenuhan kebutuhan rumah tangga diperoleh dari kegiatan pertanian, peternakan, dan kegiatan diluar pertanian peternakan. Bekerja identik dengan memiliki mata pencaharian sebagai kegiatan sehari-hari yang dilakukan perempuan untuk memperoleh pendapatan. Mata pencaharian dalam penelitian ini adalah pekerjaan pokok menurut pengakuan perempuan. 
Tabel 2. Perempuan Menurut Mata Pencaharian

\begin{tabular}{llrr}
\hline No & Mata Pencaharian Pokok & $\mathrm{f}$ & $\%$ \\
\hline 1 & Petani/peternak & 29 & 72,5 \\
2 & Buruh pertanian/peternakan & 1 & 2,5 \\
3 & Pegawai negeri dan swasta & 0 & 0 \\
4 & Wiraswasta dan perdagangan & 6 & 15 \\
5 & Buruh (selain buruh pertanian/ peternakan) & 3 & 7,5 \\
6 & Lain-lain/tidak bekerja & 1 & 2,5 \\
Jumlah & & 40 & $100 \%$ \\
\hline
\end{tabular}

(Sumber: Data primer tahun 2014)

Perempuan wilayah penelitian sebenarnya memiliki kegiatan utama sebagai ibu rumah tangga, namun sebagian waktu digunakan untuk membantu bekerja di pertanian terutama ketika musim labuh. Mereka menyiapkan bibit tanaman dan membantu menanam. Ketika panen dilakukan menggunakan sabit, perempuan membantu merontokkan bulir padi dari tangkai. Mata pencaharian didominasi dengan kegiatan pertanian berkat dukungan lahan pertanian yang subur. Kegiatan pertanian menjadi pilihan pekerjaan yang banyak dilakukan perempuan mencapai 75 persen yakni sebagai petani/ peternak mencapai 72,5 persen dan sebagai buruh tani 2,5 persen.

Saat ini wilayah penelitian dihadapkan dengan lahan pertanian yang semakin terbatas seiring dengan semakin terbukanya kegiatan ekonomi diluar pertanian sehingga terjadi perubahan mata pencaharian penduduk. Penduduk yang awalnya menggantungkan pertanian sebagai sumber pendapatan rumah tangga dengan semakin terbatasnya lahan pertanian, kelompok ini kemudian mencari alternatif kegiatan ekonomi diluar pertanian sebagai sumber pendapatan. Kesulitan memperoleh alternatif sumber pendapatan dari kegiatan diluar pertanian dan peternakan seringkali memaksa kelompok ini kembali lagi pada kegiatan semula yakni melakukan kegiatan pertanian dan peternakan. Ketika kelompok ini kembali ke pertanian mereka telah kehilangan lahan pertanian sehingga mereka harus menjadi buruh di pertanian.

Pendidikan merupakan investasi masa depan dalam upaya meningkatkan kualitas sumberdaya manusia. Melalui pendidikan diharapkan dapat memberikan ruang untuk perubahan berpikir agar dapat mengatasi setiap problem di masa depan. Pendidikan yang memadai menjadikan seseorang mampu menganalisis setiap informasi secara kritis dan menciptakan iklim berpikir kreatif dan inovatif.

Tabel 3. Perempuan Menurut Pendidikan

\begin{tabular}{llrr}
\hline No & Tingkat Pendidikan & $\mathrm{f}$ & \multicolumn{2}{c}{$\%$} \\
\hline 1 & Tidak Lulus SD & 4 & 10 \\
2 & SD dan sederajat & 9 & 22,5 \\
3 & SLTP dan sederajat & 19 & 47,5 \\
4 & SLTA dan sederajat & 8 & 20 \\
Jumlah & 40 & $100 \%$ \\
\hline
\end{tabular}

(Sumber: Data primer, 2014) 
Pendidikan perempuan didominasi dengan pendidikan SLTP dan sederajat yang mencapai 47,5 persen, hanya 20 persen perempuan yang memiliki pendidikan SLTA, tanpa ada yang memiliki pendidikan sampai perguruan tinggi. Pengembangan Desa Wisata Gabugan menjadi inovasi bagi perempuan di wilayah penelitian untuk mengembangkan alternatif kegiatan yang dapat dijadikan sum- ber pendapatan. Pendidikan yang lebih baik tentu akan memberi kesempatan yang lebih luas untuk menyerap inovasi untuk meningkatkan kualitas hidup perempuan.

Lahan merupakan modal penting di perdesaan untuk usahatani.Lahan merupakan variabel yang ikut menentukan pendapatan dari kegiatan pertanian.

Tabel 4. Penguasaan Lahan Rumah Tangga Miskin

\begin{tabular}{rrrr}
\hline No & Luas Penguasaan Lahan & F & $\%$ \\
\hline 1 & $<0,1$ ha & 25 & 62,5 \\
2 & $0,1-<0,25$ ha & 14 & 35 \\
3 & $0,25-0,5$ ha & 0 & 0 \\
4 & $>0,5$ ha & 1 & 2,5 \\
& Jumlah & 40 & $100 \%$ \\
\hline
\end{tabular}

(Sumber: Data primer tahun 2014)

Penguasaan lahan yang luas dengan pengelolaan optimal berarti kegiatan pertanian akan mampu menjamin pendapatan rumah tangga. Penguasaan lahan di wilayah penelitian relatif sempit dibawah 0,1 ha mencapai 62,5 persen. Lahan merupakan modal penting sebagai sumber pendapatan rumah tangga perdesaan, terutama rumah tangga yang menggantungkan sumber pendapatan dari kegiatan pertanian. Penguasaan lahan merupakan variabel penting dalam menentukan keadaan sosial-ekonomi di perdesaan.

Rumah tangga miskin dengan pendapatan yang relatif kecil alokasi pendapatan untuk memenuhi kebutuhan pangan dapat mencapai proporsi yang lebih banyak bahkan dapat mencapai seluruh pendapatan rumah tangga.

Tabel 5. Jumlah Anggota Rumah Tangga

\begin{tabular}{|c|c|c|c|}
\hline No & Jumlah Anggota Rumah Tangga & $\mathrm{f}$ & $\%$ \\
\hline 1 & Kurang atau sama dengan 3 orang & 1 & 2,5 \\
\hline 2 & $4-5$ orang & 27 & 67,5 \\
\hline \multirow[t]{2}{*}{3} & Lebih dari 5 orang & 12 & 30 \\
\hline & & 40 & 100 \\
\hline
\end{tabular}

(Sumber: Data primer tahun 2014)

Rumah tangga di wilayah penelitian didominasi oleh rumah tangga inti yakni rumah tangga yang terdiri dari suami istri dan anak oleh karena itu jumlah tanggungan relatif kecil. Jumlah anggota rumah tangga antara 4 sampai dengan 6 orang mencapai 67,5 persen responden. Semakin banyak anak tanpa didukung kemampuan ekonomi menjadi beban berat bagi rumah tangga. Jumlah tanggungan yang banyak, diperlukan modal lebih 
besar untuk setiap anggota rumah tangga mulai dari biaya untuk pendidikan, perawatan kesehatan, dan memenuhi kebutuhan konsumsi.

Sumber pendapatan rumah tangga perdesaan umumnya berasal dari kegiatan pertanian dan peternakan. Dinamika di perdesaan berdampak pada keanekaragaman kegiatan di perdesaan termasuk kegiatan ekonomi. Desa wisata merupakan alternatif kegiatan mulai berkembang menjadi sumber pendapatan di perdesaan. Kebutuhan yang semakin meningkat tanpa disertai peningkatan sumberdaya manusia pada wilayah dengan keterjangkauan kurang menguntungkan tentu saja berdampak pada tekanan terhadap sumber daya sekitar yang semakin kuat. Tentu saja dalam jangka panjang gejala tersebut dapat menjadi ancaman terhadap keberlanjutan sumberdaya.

Tabel 6. Pendapatan Rumah Tangga Per Tahun

\begin{tabular}{llrr}
\hline No & Total Pendapatan Rumah Tangga per tahun & F & \multicolumn{2}{c}{ \% } \\
\hline 1 & < Rp 15 000 000 & 8 & 20 \\
2 & Rp 15 000 000 - Rp 25 000 000 & 21 & 52,5 \\
3 & $>$ Rp 25 000 000 & 11 & 27,5 \\
Jumlah & 40 & $100 \%$ \\
\hline
\end{tabular}

(Sumber: Data primer tahun 2014)

Total pendapatan rumah tangga per tahun didominasi antara Rp15 000000 sampai dengan Rp 25000000 mencapai 52,5 persen responden. Rumah tangga miskin di wilayah penelitian memiliki keterbatasan sumber produksi, yakni pendidikan yang rendah, tanpa modal, dan tanpa lahan pertanian sehingga memiliki pendapatan rumah tangga yang reelatif rendah. Sumber pendapatan relatif homogen, yakni dari kegiatan pertanian, peternakan, dan memanfaatkan sumberdaya sekitar menjadikan rumah tangga di wilayah penelitian masih banyak yang hidup dalam kemiskinan.

Perdesaan yang masih didominasi penduduk yang menggantungkan kegiatan pertanian sebagai sumber pendapatan, maka lahan pertanian merupakan faktor produksi penting yang menentukan tingkat pendapatan rumah tangga. Pendapatan rumah tangga untuk pemenuhan kebutuhan konsumsi dipengaruhi oleh berbagai faktor, meliputi pola konsumsi, jumlah tanggungan, latar belakang, dan lingkungan sosial ekonomi. Peningkatan pendapatan rumah tangga berdampak pada pola pengeluaran konsumsi rumah tangga.

Manusia akan berusaha meningkatkan kesejahteraan hidupnya. Peningkatan kesejahteraan dilakukan dengan mengupayakan peningkatan kualitas hidup, mulai dari pemenuhan kebutuhan pangan, pakaian, kesehatan, pendidikan, dan hiburan. Masingmasing individu memiliki kebutuhan bervariasi, tergantung pada ketersediaan sumber pendapatan. Rumah tangga yang memiliki pendapatan semakin tinggi maka pengeluaran untuk kebutuhan konsumsi menjadi lebih kecil dibandingkan dengan pendapatannya. Sebaliknya, rumah tangga dengan pendapatan semakin kecil maka sebagian besar dari pendapatannya digunakan untuk memenuhi kebutuhan konsumsi. Dilihat dari bagian pendapatan yang dialokasikan untuk memenuhi kebutuhan konsumsi, sebagian besar pendapatan dari rumah tangga miskin digunakan untuk memenuhi kebutuhan konsumsi rumah tangga.

Pendapatan rumah tangga berupa seluruh pendapatan dari kegiatan pertanian, 
peternakan, dan diluar kegiatan tersebut dan berasal dari pendapatan kepala rumah tangga dan anggota rumah tangga lainnya. Setelah diketahui pendapatan rumah tangga dan jumlah anggota rumah tangga yang menjadi tanggungan setiap rumah tangga kemudian ditentukan pendapatan per kapita. Pendapatan per kapita per tahun ditentukan berdasarkan pendapatan rumah tangga per tahun berbanding dengan jumlah anggota rumah tangga yang menjadi tanggungan.

Tabel 7. Rumah Tangga Berdasarkan Pendapatan Per Kapita Per Tahun

\begin{tabular}{llrr} 
No & Pendapatan per kapita per tahun & $\mathrm{f}$ & $\%$ \\
\hline 1 & $\begin{array}{l}\text { Kurang atau sama dengan dan kurang dari Rp 1980.000 (setara 180 } \\
\text { kg beras per kapita per tahun) }\end{array}$ & 15 & 37,5 \\
2 & $\begin{array}{l}\text { Antara Rp 1.980.000 hingga kurang dari dan sama dengan Rp } \\
\text { 2.640.000(setara 180 kg hingga 240 kg beras per kapita per tahun) }\end{array}$ & 17 & 42,5 \\
3 & Lebih dari Rp 2.640.000 (setara 240 kg beras per kapita per tahun) & 8 & 20 \\
Jumlah & 40 & $100 \%$ \\
\hline
\end{tabular}

(Sumber :Data Primer tahun 2014)

Pendapatan per kapita per tahun setara beras paling banyak setara dengan $240 \mathrm{~kg}$ beras, setara nilai Rp 2640000 per kapita per tahun mencapai 42,5 persen responden, dengan pendapatan per kapita per tahun kurang dari atau sama dengan $180 \mathrm{~kg}$ beras setara dengan Rp 1980000 mencapai 37,5 persen. Sesuai dengan kriteria dari Sayogjo bahwa rumah tangga di wilayah penelitian masih didominasi rumah tangga miskin. Pendapatan per kapita dapat dijadikan salah satu indikator untuk mengetahui tingkat kesejahteraan penduduk. Pendapatan per kapita yang semakin baik, berarti kesempatan peningkatan sumberdaya manusia menjadi lebih terbuka.

Peningkatan kualitas perempuan dilakukan melalui peningkatan pendidikan, perbaikan kesehatan, peningkatan pendapatan, dan peningkatan kualitas hidup. Pendidikan dapat membuka wawasan serta menjadikan seseorang lebih leluasa dapat memanfaatkan setiap kesempatan memperoleh sumber pendapatan guna meningkatkan kesejahteraan hidupnya. Pendapatan yang memadai membuka kesempatan untuk melakukan investasi, peningkatan kualitas pangan, gizi, penyediaan papan, serta mendukung terciptanya lingkungan yang kondusif untuk meningkatkan kualitas hidup.

Peningkatan kualitas perempuan melalui peningkatan pendidikan, keterampilan, perbaikan kesehatan, dan pemenuhan kebutuhan lainnya menjadi modal penting bagi perempuan untuk memperoleh sumber pendapatan memadai. Peningkatan kesejahteraan akan dapat dilakukan lebih mudah apabila rumah tangga memiliki pendapatan per kapita tinggi. Pendapatan per kapita yang memadai memberi kesempatan untuk menyisihkan sebagian pendapatan tidak hanya untuk memenuhi kebutuhan konsumsi tetapi juga untuk meningkatkan kualitas hidup termasuk meningkatkan kesejahteraan.

\section{Upaya Perempuan Dalam Pengentasan Kemiskinan}

Perempuan di wilayah penelitian selalu berupaya untuk membantu laki-laki mengatasi kesulitan ekonomi. Kegiatan ekonomi di wilayah penelitian yang dapat dilakukan perempuan relatif terbatas. Perempuan 
melakukan upaya untuk mengatasi kesulitan ekonomi di rumah tangga mereka antara lain dengan diversifikasi usaha (pertanian, perdagangan, jasa, pariwisata), mengerahkan kekuatan untuk menambah pemasukan atau penghasilan rumah tangga dengan mengerahkan semua anggota rumah tangganya un- tuk ikut bekerja, berhutang untuk memenuhi kebutuhan hidup, menghemat pengeluaran agar dapat menabung, mengurangi jatah makan, mengurangi kualitas konsumsi makanan, melakukan migrasi untuk memperoleh pekerjaan, dan meminta bantuan dari famili.

Tabel 8. Upaya Pengentasan Kemiskinan Melalui Diversifikasi Usaha

\begin{tabular}{llrrr}
\hline No & Diversifikasi Usaha & f & \multicolumn{2}{c}{$\%$} \\
\hline 1 & Pertanian & 4 & 10 \\
2 & Perdagangan & 6 & 15 \\
3 & Jasa & 3 & 7,5 \\
4 & Pariwisata & 7 & 17,5 \\
5 & Lain-lain & 1 & 2,5 \\
6 & Tidak Melakukan Diversifikasi Usaha & 19 & 47,5 \\
\multicolumn{2}{l}{ Jumlah } & 40 & $100 \%$ \\
\hline
\end{tabular}

(Sumber: Data primer tahun 2014)

Dilihat dari kondisi rumah tangga di wilayah penelitian sebenarnya masih dijumpai dominasi rumah tangga dalam kategori rumah tangga miskin (ukuran pengeluaran setara beras per kapita per tahun). Kondisi rumah tangga miskin akan menyulitkan perempuan karena dampak kemiskinan akan dirasakan paling berat oleh perempuan. Perempuan akan berusaha untuk mengatasi kemiskinan dengan berbagai upaya, karena perempuan menyadari ketika rumah tangganya dalam kesulitan ekonomi oleh lilitan kemiskinan mereka yang paling merasakan penderitaan tersebut.

Perempuan yang memiliki kesempatan dan waktu luang akanmencoba masuk dalam kegiatan ekonomi apa saja dengan keterbatasan modal yang dimiliki, tujuan utamanya agar dapat menyelamatkan rumahtangganya dari lilitan kemiskinan. Keterbatasan modal dan keterbatasan kesempatan kerja yang tersedia memaksa perempuan tidak baanyak melakukan diversifikasi usaha guna mengatasi lilitan kemiskinan yang dialami. Perempuan yang tidak melakukan diversifikasi usaha mencapai 47,5 persen.

Pengembangan Desa Wisata Gabugan mulai menolong perempuan di wilayah tersebut dalam membebaskan rumah tangganya dari belenggu kemiskinan. Dijumpai 17,5persen perempuan menjatuhkan pilihan melakukan diversifikasi usaha dengan memanfaatkan wisatawan yang datang dengan berbagai usaha seperti menyediakan aneka makanan tradisional dan membuat souvenir untuk wisatawan.Perempuan melakukan diversifikasi usaha terkait pariwisata dengan melibatkan 17,5 persen perempuan melalui usaha pemenuhan keperluan wisatawan mulai dari kuliner, souvenir, dan penginapan. 
Tabel 9. Upaya Pengentasan Kemiskinan Melalui Penghematan Pengeluaran

\begin{tabular}{llrr}
\hline No & Penghematan Pengeluaran & f & \multicolumn{2}{c}{$\%$} \\
\hline 1 & Pangan & 24 & 60 \\
2 & Pakaian & 10 & 25 \\
3 & Sosial & 4 & 10 \\
4 & Lain-lain & 2 & 5 \\
Jumlah & & 40 & $100 \%$ \\
\hline
\end{tabular}

(Sumber: Data primer tahun 2014)

Perempuan di wilayah penelitian melakukan berbagai upaya pengentasan kemiskinan mulai dari mencari sumber pendapatan dengan melakukan kegiatan ekonomi sampai mengelola rumah tangga terkait pengeluaran yang harus dialokasikan untuk pemenuhan kebutuhan rumah tangga mereka. Perempuan di wilayah penelitian sebagian besar (60 persen) melakukan upaya pengentasan kemiskinan dengan menekan pengeluaran untuk keperluan pangan. Pangan yang dikonsumsi ditekan kualitas maupun kuantitasnya agar anggaran rumah tangga dapat mencukupi untuk pemenuhan kebutuhan pangan seluruh anggota rumah tangga. Menekan pengeluaran untuk pakaian mencapai 20 persen tertinggi setelah pangan. Kebutuhan primer manusia berupa kebutuhan pangan, papan, dan sandang terkait dengan pola hidup individu, pendapatan rumah tangga, jenis pekerjaan, dan lingkungan. Kebutuhan pangan di wilayah penelitian banyak dicukupi dari hasil kebun sendiri terutama untuk makanan pokok sehari-hari. Pemenuhan kebutuhan sandang bagi perempuan perdesaan relatif sederhana memerlukan alokasi biaya yang sedikit. Perdesaan dengan mata pencaharian utama pertanian dan peternakan diperlukan pakaian yang lebih sederhana dibandingkan dengan mereka yang mempunyai mata pencaharian formal di luar pertanian dan peternakan.

Pengentasan kemiskinan selain dengan menekan pengeluaran, perempuan di wilayah penelitian melakukan alternatif pengentasan kemiskinan mulai dari mengerahkan anggota rumah tangga untuk bekerja, berhutang untuk memenuhi kebutuhan pokok, melakukan migrasi dengan bekerja di luar wilayah penelitian, dan meminta bantuan dari famili untuk memenuhi kebutuhan mendesak.

Tabel 10. Alternatif Upaya Pengentasan Kemiskinan

\begin{tabular}{llrr}
\hline No & \multicolumn{1}{c}{ Alternatif Pengentasan Kemiskinan } & $\mathrm{f}$ & $\%$ \\
\hline 1 & $\begin{array}{l}\text { Mengerahkan seluruh anggota rumah tangga untuk ikut memperoleh } \\
\text { pendapatan }\end{array}$ & 8 & 20 \\
2 & Berhutang untuk memenuhi kebutuhan hidup & 18 & 45 \\
3 & Melakukan migrasi untuk memperoleh pendapatan & 11 & 27,5 \\
4 & Meminta bantuan dari famili & 5 & 12,5 \\
Jumlah & 40 & $100 \%$ \\
\hline
\end{tabular}

(Sumber: Data primer tahun 2014) 
Mengerahkan seluruh anggota rumah tangga ikut bekerja agar memperoleh pendapatan guna memenuhi kebutuhan rumah tangga dilakukan sebagai alternatif pengentasan kemiskinan. Cara tersebut dilakukan oleh 20 persen rumah tangga miskin. Berhutang untuk memenuhi kebutuhan rumah tangga miskin menjadi salah satu alternatif pengentasan kemiskinan mencapai 45 persen rumah tangga melakukan cara ini sebagai solusi pengentasan kemiskinan, dan 27,5 persen rumah tangga melakukan migrasi untuk mencari sumber pendapatan di wilayah lain agar mampu terlepas dari lilitan kemiskinan. Kekerabatan yang masih kental di perdesaan ternyata tidak banyak dijadikan alternatif pengentasan kemiskinan ditunjukkan hanya 12,5 persen rumah tangga yang memanfaatkan famili untuk pengentasan kemiskinan.

\section{Kendala Perempuan Dalam Pengentasan Kemiskinan}

Pendekatan kebutuhan dasar, melihat kemiskinan sebagai suatu ketidakmampuan (lack of capabilities) seseorang, keluarga, dan masyarakat dalam memenuhi kebutuhan minimum, antara lain pangan, sandang, papan, pelayanan kesehatan, pendidikan, penyediaan air bersih dan sanitasi.Kendala yang dihadapi perempuan dalam upaya pengentasan kemiskinan antara lain adanya keterbatasan akses terhadap kesehatan oleh rumah tangga miskin, keterbatasan rumah tangga miskin memperoleh pendidikan yang memadai, keterbatasan kesempatan berusaha dan memperoleh sumber pendapatan, kondisi sanitasi yang masih memprihatinkan, dan ketidaksetaraan gender.

Aksesibilitas yang relatif baik memudahkan penduduk untuk memperoleh pemenuhan kebutuhan konsumsi yang banyak tersedia di sekitar tempat tinggal. Kebutuhan konsumsi dapat diperoleh perempuan di wilayah penelitian mulai dari yang dijajakan oleh pedagang keliling, tersedia di warungwarung dusun, di pasar, atau tempat belanja yang lebih jauh dari tempat tinggal asal dengan mudah dapat dijangkau. Kebutuhan konsumsi rumah tangga miskin lebih seder- hana, bahkan sebagian konsumsi pangan diperoleh dari memanfaatkan hasil pekarangan. Apabila pedagang dan warung yang menyediakan barang-barang pemenuhan kebutuhan sehari-hari di perdesaan terbatas, perempuan akan lebih banyak memerlukan waktu untuk memenuhi kebutuhan seharihari dengan pergi ke pasar. Mobilitas penduduk dilakukan menggunakan transportasi umum yang mudah diperoleh setiap saat serta menggunakan kendaraan yang dimiliki untuk melakukan mobilitas dalam jarak dekat maupun jarak jauh.

Pertukaran gagasan dapat dilakukan dengan memanfaatkan fasilitas komunikasi dan informasi, meskipun cara penyebaran secara langsung masih banyak dijumpai di perdesaan. Perempuan telah banyak memanfaatkan sarana komunikasi dan sumber informasi, seperti telepon rumah, telepon genggam, jasa pos, televisi, radio, dan surat kabar untuk keperluan sosial, ekonomi, hiburan, dan kepentingan lain. Fasilitas komunikasi dan informasi (telepon, pos, televisi, surat kabar, majalah, dan sebagainya) telah menjadi kebutuhan untuk memperoleh berbagai informasi.

Kesehatan merupakan salah satu indikator kesejahteraan, dengan kesehatan yang terjamin, seseorang dapat meningkatkan sumberdaya pribadi melalui pendidikan, keterampilan, pendapatan, dan melakukan kegiatan lainnya. Kegiatan setiap hari dapat berjalan lancar apabila didukung dengan kesehatan memadai. Kemudahan memperoleh pelayanan kesehatan berarti terjaminnya kesehatan akan berdampak pada peningkatan kesejahteraan. Aksesibiltas yang menguntungkan dengan kemudahan menjangkau tempat pelayanan kesehatan setiap saat dengan mudah dapat diperoleh penduduk.

Biaya yang harus disediakan untuk memperoleh pelayanan kesehatan menjadi kendala dari rumah tangga miskin untuk memperoleh pelayanan kesehatan sesuai dengan pilihan yang diharapkan. Hanya rumah tangga yang memiliki kemampuan ekonomi memadai yang memperoleh pelayanan kesehatan lebih baik. Kesulitan ekonomi 
menyebabkan perbedaan kesempatan memperoleh pelayanan kesehatan bagi setiap rumah tangga. Rumah tangga miskin hanya mampu menjangkau pelayanan kesehatan yang kurang memadai berbeda dengan rumah tangga kaya yang dapat mencari pilihan pelayanan kesehatan sesuai dengan kemampuan yang dimiliki. Rumah tangga dengan kemampuan ekonomi terbatas akhirnya kurang memperhatikan kesehatan karena keterbatasan biaya yang harus disediakan untuk biaya kesehatan.

Fasilitas kesehatan telah tersedia cukup baik dengan keterjangkauan yang mudah seperti puskesmas, bidan, dokter praktik, dan klinik untuk rawat inap.Sanitasi dan lingkungan menjadi instrumen penting dalam mewujudkan kesejahteraan masyarakat, ketika sanitasi dan lingkungan buruk maka kesehatan masyarakat akan terganggu karena ancaman berbagai penyakit. Biaya kesehatan dan gangguan kesehatan yang harus dibayar menjadi kendala yang menghambat seseorang untuk mengalokasikan biaya dan waktu untuk memperbaiki kesejahteraannya.

\section{SIMPULAN}

Perempuan di rumah tangga wilayah penelitian memiliki kegiatan utama sebagai ibu rumah tangga. Kemiskinan banyak dialami perempuan, meskipunkondisi tersebut tidak serta merta mendorong perempuan terlibat dalam kegiatan ekonomi untuk melepaskan lilitan kemiskinan yang dialami. Rendahnya tingkat pendidikan dan semakin sempitnya luas penguasaan lahan mendominasi karakteristik perempuan di rumah tangga miskin. Upaya yang dilakukan perempuan untuk melepaskan lilitan kemskinan mulai dari melakukan diversifikasi usaha (meskipun hanya dilakukan oleh sebagian kecil perempuan), mensiasati pengeluaran terkait pangan, sandang, dan keperluan sosial. Mengerahkan seluruh anggota rumah tangga ikut bekerja agar memperoleh pendapatan, berhutang untuk memenuhi kebutuhan rumah tangga miskin, melakukan migrasi untuk mencari sumber pendapatan di wilayah lain, dan memanfaatkan famili untuk pengentasan kemiskinan. Kendala pengentasan kemiskinan antara lain keterbatasan akses terhadap kesehatan oleh rumah tangga miskin, keterbatasan perempuan dan anggota rumah tangga miskin memperoleh pendidikan yang memadai, memperoleh kesempatan berusaha dan memperoleh sumber pendapatan. Kondisi sanitasi yang buruk dan ketidaksetaraan genderikut memperparah keterpurukan perempuan sehingga sulit melepaskan mereka dari lilitan kemiskinan.

\section{UCAPAN TERIMA KASIH}

Kami mengucapkan terimakasih kepada :

1. Dekan FIS UNY, Prof. Dr. Ajat Sudrajat, M.Ag. yang telah memberikan fasilitas berupa ijin pelaksanaan penelitian.

2. Bapak/ibu dosen Jurusan Pendidikan Geografi, FIS, UNY yang telah memberikan bantuan moral serta masukan untuk kebaikan penelitian ini.

\section{DAFTAR PUSTAKA}

Baiquni. 2006.Pengelolaan Sumberdaya Perdesaan Dan Strategi Penghidupan Rumahtangga di DIY Masa Krisis (19982003). Disertasi. UGM Yogyakarta

BPS. 2011. Biro Pusat Statistik. Jakarta

Chambers. 1983.Pembangunan Desa Mulai Dari Belakang.Jakarta: LP3ES

Cotter, David A. 2002.Poor people in poor places: Local opportunity structures and household poverty, Rural Sociology; Dec 2002; 67, 4; Agriculture Journals, p. 534

Sajogyo.1986.PembagianKerjaantaraPriadanWanitadiBidangPertanian. Buku kenang-kenangan untuk Selo Sumardjan. Bogor

UNDP. 2006. Era Baru Dalam Pengentasan Kemiskinan: The World Bank Office. Jakarta. 